https://doi.org/10.48009/2_iis_2010_14-21

\title{
ONLINE COURSE EXPERIENCE MATTERS: INVESTIGATING STUDENTS' PERCEPTIONS OF ONLINE LEARNING
}

\author{
Marzie Astani, Winona State University, mastani@ winona.edu \\ Kathryn J. Ready, Winona State University, kready@ winona.edu \\ Edward A. Duplaga, Winona State University, eduplaga@ winona.edu
}

\begin{abstract}
$=$ ニニニニニニニニニニニ

ABSTRACT

With the rapid growth of online programs, many higher educational institutions are considering offering online courses and programs to better serve students that have grown up in a technological era. Although many higher educational administrators recognize the value and flexibility of online education, research is needed concerning course design, assessment, and student's perceptions of online programs before allocating more resources for online programming. This study examines student's perceptions of online courses/programs and concludes that higher levels of experience with online learning lead to more favorable perceptions about online courses. Suggestions for higher education institutions considering the adoption of online courses/programs are provided.
\end{abstract}

Keywords: Online learning, experience, Students' perception, Quality of online courses

\section{INTROD'UCTION}

Today's students, having grown up in a technological era, are seeking new, innovative forms of course delivery; many higher educational institutions are attempting to meet this demand by adopting online course offerings. Researchers have documented this rapid increase in online course delivery. Pethokoukis [21] reported a 33\% per year increase in online enrollment in the U.S. through 2002. In a study report of 277 AACSB member schools [1] 9\% of institutions reported at least one online program in 2001-2002. By 2008-09, 24\% of these schools offered online programs. Similarly, in a 2005 research study of education in the U.S, the growth rate for online enrollment was reported at $18.8 \%$, which exceeded the overall growth rate in the higher education student body [3]. The largest increase (72\%) was for associate degree institutions; sixty-five percent of schools were offering traditional graduate

Volume XI, No. 2, 2010 programs along with online courses, and sixty-three percent of traditional undergraduate programs offered online courses [3]. Overall, fifty-six percent of higher educational institutions identified online education as a critical long-term strategy. In order to be competitive in the educational marketplace, higher educational institutions are increasingly considering online course offerings as part of their strategic planning process.

In spite of widespread growth and expanding online program offerings, there have been controversies regarding the quality of online education. Several studies have been conducted comparing online with traditional face-to-face learning concerning the design, effectiveness, and students' performance as indicators of course quality. For example, McFarland and Hamilton [18] examined the level of student engagement as an indicator of quality and found no difference in satisfaction or performance of students enrolled in online versus those students enrolled in traditional courses. In another study, Russel [28] focused on student exam performance and found that learning outcomes were comparable in both online and traditional teaching modes. Klesius et. al. [15] found that learners' satisfaction with online learning was the same as traditional face-to-face courses.

Other studies have focused on the target audience to better understand student perceptions of online learning. For example, Ponzurick et. al. [24] found that learners prefer the traditional face-to-face method of delivery over the online learning approach. In the 2005 Quarterly Review of Distance Education, more than $40 \%$ of responding institutions reported that student satisfaction with online courses was similar to satisfaction with traditional courses [30]. Other research studies have shown that students understand the positive aspects of online learning, 
such as not spending time to drive to attend class, the flexibility to work at their own pace, more course availability, and interacting socially with others with decreased inhibitions [5, 9, 30]. However, more research studies are needed to understand the students' perceptions of online learning to help higher educational institutions better serve learners. This study is intended to examine students' perceptions of the online learning environment. Prior experience in online learning and its effect on student perceptions is investigated. A brief literature review of online learning is followed by the research methodology and results. Finally, the discussion of student perceptions and conclusion will be presented.

\section{LITERATURE REVIEW}

Advantages of online learning, such as learning anytime and anyplace have been noted in several studies [2, 16, 22]. Many research studies have been conducted comparing the two delivery systems, online and face-to-face settings, and concluded that there is no significant difference in the learning outcomes of students in both systems (e.g., [20]). Others reported that online students showed higher levels of engagement than those of traditional learners and students gained knowledge and acquired skills that facilitated their understanding of realworld and job-related problems [26]. Furthermore, some researchers propose that the online environment facilitates lifelong quality learning [2], which contributes to students' daily lives [7]. Moreover, Reynolds [25] found that the majority of students had to work harder to meet academic expectations in online courses. In their research study, Conrad and Donaldson [10] reported that online participants worked collaboratively with other students and demonstrated a high level of engagement in critical and analytical thinking. Technology employed in online environment is believed to enrich learning and creates meaningful experiences that contribute to the learner's growth and development [10]. Robinson and Hullinger [26] suggest that the learner's autonomy to learn on their own is a major advantage to online learning.

However, some researchers have raised concerns related to a potential compromise in quality and learning experience for online versus traditional face-

Volume XI, No. 2, 2010 to-face learning [26, 8]. Some studies have cited several disadvantages in online courses, including lack of interaction (student-to-instructor and/or student-to-student), privacy issues, technological difficulties, and a focus on technology rather than content (e.g., [5, 23]). The lack of students' engagement and isolation are issues in online learning since most of the online courses are asynchronous, allowing learners to participate from different locations, and thereby may result in learners' feeling of isolation. To address this issue, Kuh [16] recommends that students should be provided with opportunities to contribute to class discussion, work with other students, and engage in other class activities. Researchers conclude that the online environment should foster collaborative efforts to promote learning and create a learning community, which is very different from many traditional education programs $[4,6]$. Researchers recommend that collaborative activities need to be embedded in online learning to provide opportunities for learners to increase social presence, reduce feelings of isolation and gain a sense of online community. This process involves participants learning through interactions with their peers $[11,27]$. Further, Hinltz \& Turoff [12] argue that learners' anxiety and uncertainty are reduced as learners communicate with their teammates to find solutions to complex problems or new tasks, instead of alone, or just with the instructor [31].

From the students' perspective, online courses offer several benefits; students are able to customize the online learning environment to adapt to their life style, resulting in increased flexibility, and better use of time [13]. Unfortunately, there is a paucity of research studies exploring students' perspectives about online learning, such as quality of learning, collaborative opportunities, teamwork skills, and technology embedded in online learning. This research study is aimed at understanding students' perspectives about online learning and will provide insights that could help higher education institutions with developing and promoting online course offerings.

\section{RESEARCH METHODOLOGY}

To understand students' perspectives of online learning, a survey was developed after reviewing the 
literature. Survey items using a Likert scale were developed, and included questions about online learning characteristics and course design. The first two questions were demographic questions about the student's academic major and experience with online learning. A random sample of 280 business students was included in the survey. The participants' academic fields included Business Administration, Marketing, Human Resource Management, Management Information Systems, Finance, Accounting, and others. As Figure 1 shows, over fifty percent of the respondents were Business Administration major s. Finance majors represented only 2 percent of the respondents.

Figure 1. Majors of respondents

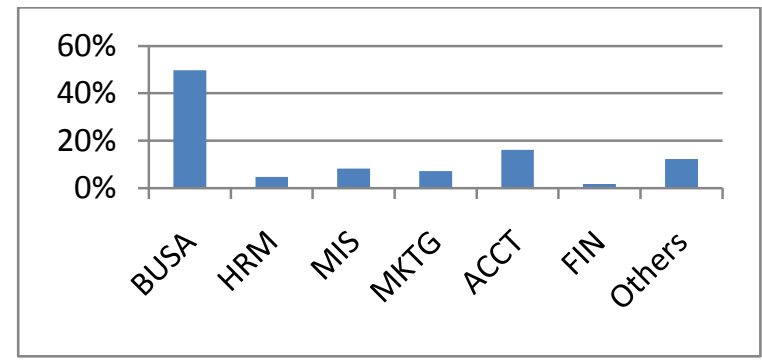

Figure 2 shows a comparative graph of respondent's online learning experience. Twenty percent of student respondents had no experience in online courses, fifty-three percent of respondents had limited experience (had taken 1-3 online courses) and twenty-seven percent of respondents were experienced with online courses (had taken 4 or more online courses).

Figure 2. Number of online courses taken by students

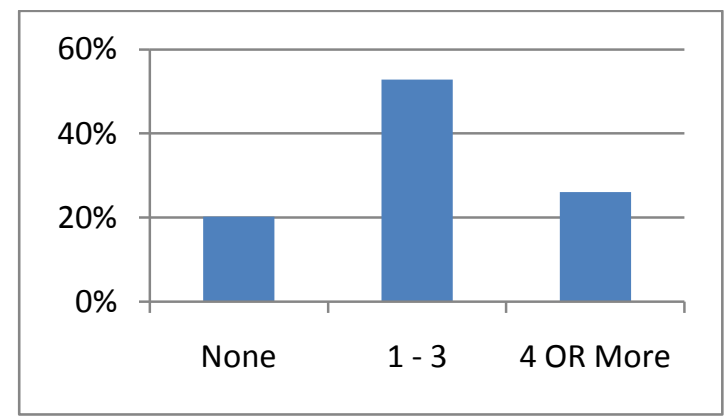

\section{RESULTS}

In addition to the student background questions, there were eighteen other questions in the survey related to online learning characteristics and issues. The average ratings for the questions are presented in Table 1. As shown in the table, almost all participants involved in the survey agreed that "Compared to traditional classes, online courses offer more flexibility." The average rating for this survey item is the highest in the questionnaire (4.46). One of the important issues mentioned in the literature is technology in the online learning environment. The students involved in our survey did not feel that technology was a problem as shown by item number 8. The average rating of 2.39 indicates that the majority of the students in our survey did not agree that "technology is a barrier to online learning." This does not support the claim of some previous research studies that technology is an issue for students in the online environment (e.g., [5, 23]).

As shown in Table 1, students involved in our survey believed that online courses are as rigorous as traditional (item number 3 ) and offer the same course material (item number 7). The students in our study thought that online learning was challenging (item number 5). Our findings are consistent with the literature that indicates that online courses need to be engaging and challenge learners because online students are dispersed in time and place due to their asynchronous nature [6]. Our students stated that they plan on taking online courses in the future (item number 19 with an average rating of 3.73), and feel that there should be the same level of reimbursement for online courses as traditional face-to-face courses (item number 20). Overall, students expressed uncertainty as to if student's learned as much in online courses as in traditional face-to-face courses (item number 9), if online courses gave them an opportunity to interact with others (item number 10), if online courses offered them an opportunity to voice their opinion (item number 12), if the rigor of and online degree is the same as a face-to-face program degree (item number 14), or if they would consider a degree from an online and traditional university the same when it came to hiring decisions (item number 15). The average ratings for these characteristics were $3.33,2.72,2.96,3.01$, and 3.08, respectively. 
Table 1 . Average ratings for the survey items ( $1=$ Strongly disagree through $5=$ Strongly agree $)$

\begin{tabular}{|l|c|}
\hline \multicolumn{1}{|c|}{ Survey items } & Average Rating \\
\hline 3. Online courses are as rigorous as traditional face-to-face. & 3.60 \\
\hline 4. I would rate the quality of online learning as excellent. & 3.51 \\
\hline 5. Online course(s) are intellectually challenging. & 3.83 \\
\hline 6. Compared to traditional classes, online courses offer more flexibility. & 4.46 \\
\hline 7. Online and traditional courses offer the same course material. & 3.68 \\
\hline 8. Technology is a barrier to online learning. & 2.39 \\
\hline 9. Students learn as much in online course as they do in a traditional face-to-face. & 3.33 \\
\hline 10. Online courses do NOT provide opportunity for interaction with others. & 2.72 \\
\hline 11. Online courses provide opportunity for teamwork skill development. & 3.21 \\
\hline 12. Online courses provide better opportunity to voice opinion. & 2.96 \\
\hline 13. Online courses provide better opportunity to use technology and related resources. & 3.98 \\
\hline 14. Online and traditional universities' degree are of equal in rigor. & 3.01 \\
\hline $\begin{array}{l}\text { 15. In hiring decisions, I would consider a degree from online and traditional universities of } \\
\text { the same quality. }\end{array}$ & 3.08 \\
\hline 16. In my future job, if a university degree was required for a position, I would most likely \\
NOT hire someone with an online degree. & 2.64 \\
\hline 17. I would recommend online courses to my coworkers to further develop their skills. & 3.78 \\
\hline 18. I would recommend traditional face-to-face courses ONLY to my coworkers. & 2.89 \\
\hline 19. I plan on taking online courses in the future. & 3.73 \\
\hline 20. Online and traditional courses should be reimbursed at the same level. & 3.94 \\
\hline
\end{tabular}

The second objective of this study was to determine if differences in students' online experiences would impact their perceptions of online learning. To this end, we developed the following hypothesis:

Hypothesis: Experience plays a significant role in students' perception of online learning.

Analysis of variance (ANOVA) was used to compare the differences between the three categories (no experience, limited experience, and experienced). Further statistical analyses were performed for those items in the survey showing significant difference to find out which group differs significantly in their average ratings.

The results of the ANOVA showed that only one survey item was not significantly different across the groups ( item number 12). A closer look into the average ratings for each group showed that all groups were uncertain about whether online courses offered students better opportunities to voice their opinion than traditional face-to-face classes. According to the literature, one of the advantages of online learning is that it provides a non-judgmental environment so that students will not be intimidated. As Dennis Killian [14] indicated "In some cases, an e-learning environment builds a stronger support system than that found in brick-and-mortar classrooms, because students may feel intimidated speaking up in a traditional classroom." But, our respondents indicated uncertainty as to if this difference existed between online and face-to-face learning environments. 
Table 2. Significant difference in opinion between groups

\begin{tabular}{|l|l|c|c|}
\hline \multicolumn{1}{|c|}{ Survey items } & \multicolumn{3}{c|}{ Groups' Opinion } \\
\hline & No exp & $\begin{array}{c}\text { Limited } \\
\text { exp }\end{array}$ & Exp \\
\hline 3. Online courses are as rigorous as traditional & Uncertain & Agree & Agree \\
\hline 4. I would rate the quality of online learning as excellent & Uncertain & Uncertain & Agree \\
\hline 5. Online course(s) are intellectually challenging & Agree & Agree & Agree \\
\hline 6. Online courses offer more flexibility & Agree & $\begin{array}{c}\text { Strongly } \\
\text { Agree }\end{array}$ & $\begin{array}{c}\text { Strongly } \\
\text { Agree }\end{array}$ \\
\hline 7. Online and traditional courses offer the same course material & Uncertain & Agree & Agree \\
\hline 8. Technology is a barrier to online learning & Uncertain & Disagree & Disagree \\
\hline 9. Students learn the same in online and traditional courses & Uncertain & Uncertain & Agree \\
\hline 10. Online courses do NOT provide opportunity for interaction & Uncertain & Disagree & Disagree \\
\hline 11. Online courses provide teamwork skill opportunities & Uncertain & Uncertain & Agree \\
\hline 12. Online courses provide better opportunity to voice opinion & No Significant difference \\
\hline 13. Online courses provide better opportunity to use technology & Agree & Agree & $\begin{array}{c}\text { Strongly } \\
\text { Agree }\end{array}$ \\
\hline 14. Online and traditional universities' degree are of equal in rigor & Uncertain & Uncertain & uncertain \\
\hline 15. Online and traditional degrees are of the same quality & Uncertain & Uncertain & Agree \\
\hline 16. I would most likely NOT hire someone with an online degree & Uncertain & Disagree & Disagree \\
\hline 17. I would recommend online courses & Uncertain & Agree & $\begin{array}{c}\text { Strongly } \\
\text { Agree }\end{array}$ \\
\hline 18. I would recommend traditional face-to-face courses ONLY & Uncertain & Disagree & Disagree \\
\hline 19. I plan on taking online courses in the future. & Agree & Agree & $\begin{array}{c}\text { Strongly } \\
\text { Agree }\end{array}$ \\
\hline $\begin{array}{l}\text { 20. Online and traditional courses should be reimbursed at the } \\
\text { same level }\end{array}$ & Agree & Agree & $\begin{array}{c}\text { Strongly } \\
\text { Agree }\end{array}$ \\
\hline
\end{tabular}

Further statistical analysis was needed for all other survey items showing significant differences. We used Fisher's LSD procedure to determine where the differences occur. The results of this procedure revealed that there were significant differences mainly between the group with no experience and the experienced group. Furthermore, for items 7 through 9 of the survey, significant differences were found between all groups. Looking more closely into the ratings of these items revealed that the first group with no experience in online learning was uncertain about several survey items such as the online courses providing the same course material as traditional classes, technology being a barrier in online classes, and students' learning as much in online courses as they do in traditional classes. Overall, the results support the hypothesis that online learning experience plays a significant role in students' perception.

Table 2 shows the groups' opinions where significant differences existed. As presented in the table, all groups agreed (in various degrees) that online courses are intellectually challenging (item number 5). But there was unanimous uncertainty (of various degrees) about whether a degree from an online university is of equal rigor as that of a traditional face-to-face university (item number 14). This is inconsistent with the beliefs of some researchers stating that there is no difference in the quality of the online and traditional courses (e.g., [20]). Perhaps this can be explained by Norton and Hathaway's [19] findings 
that "regardless of the learning environment, the role of the instructor/facilitator/mentor was essential." They stated that when the students perceived a lack of attention and rigor in the implementation of the instructor's role, it was a significant factor in diminishing the learning experience.

Unlike some researchers beliefs that technology is an issue for students in the online environment (e.g., [5, 23]), the majority of our students disagreed (with various degrees). Only the group with no experience was uncertain about technology being an issue. All groups agreed (with various degrees) that "online courses provide better opportunity to use technology." Also, the results of our study show that experienced students thought that the online learning environment provides opportunities for interaction with others and teamwork skill. It seems that the more experience students have with online learning, the more they realize the opportunities provided for online team activities. Experience in teamwork online is particularly important in today's virtual work environment. This is consistent with the literature that "e-learning actively involves the student in the learning process, providing for increased student satisfaction" [29]. We found that the more the experience with online learning, the more satisfied the learner becomes.

\section{CONCLUSION AND SUGGESTIONS}

There are several research implications for this study. An important finding in our study is that previous online experience of students results in significant differences in their perception of the online learning environment. Those students who had no experience with online courses were uncertain about many features of online learning and didn't know what to expect. The experienced students in our survey showed that they were satisfied with the online courses, and they would recommend online courses to others. This result demonstrates that more experience with online learning results in more satisfaction with online learning overall. Consequently, the inexperienced students will not be attracted to online courses if no attempt is made to educate them about the online learning process. In light of growing interests in online learning in higher education institutions, perhaps some introductory information can be included about online learning in the orientation program for freshmen students to familiarize them with this delivery system. These students may then be more willing to enroll in online courses during their academic program later on. The incorporation of online learning education would be an important part of the higher educational institution's strategic plan in increasing student enrollment in online courses.

Based on our findings, the participants in our study believe that the quality of online courses is as good as the traditional face-to-face learning. Our participants believed that the rigor and course material of online and traditional courses are the same ((items 3 and 7), and online courses are excellent, challenging, and provide opportunity for interaction (items 4,5 , and 10). But, our students were uncertain about whether “online and traditional universities' degrees are of equal rigor." This would seem to indicate a willingness by students to incorporate some online learning in their course program, but would feel that a totally online program would not provide them with the same experiences as a mixed face-to-face and online experience does. It seems that our students make distinction between online courses offered by traditional universities and that of online institutions.

Finally, participants' uncertainty about equal rigor of learning experience and degree obtained from online and traditional environments could be attributed to students' perception that is formed by internal and external communities. Perhaps researchers should focus their efforts on more research studies to understand students' expectations and capture the underlying reasons about the learning experience offered by the online institutions. Further, research is needed to examine the extent that online courses could/should be incorporated as part of a traditional program, if students outside the business area (e.g., education or nursing) would concur with business student perceptions of online learning, and, if there is a difference in gender perceptions regarding the issues examined. These are intriguing areas for future research endeavors that could help traditional and online higher education institutions to better course design and learning model implemented in online courses. 


\section{REFERENCES}

1. AACSB Member Schools are Increasing Online Program Offerings. April/May 2010. Available

from: http://www.aacsb.edu/publications/enewslin e/datadirect.asp. [accessed 04/16/2010].

2. Aggarwal, A. K. and Bento, R. Web-based education. In A. Aggarwal (Ed), Web-based Learning and teaching technologies: opportunities and challenges, pp. 2-160. Hershey, PA: Idea Group. 2000.

3. Allen, I. \& Seaman, J. Growing by degrees: Online education in the United States. 2005.

Available from: http://www.sloanc.org/resources/growing by degrees.pdf. [accessed 02/24/2010].

4. Barker, B. O. The internet can improve education. In H. Cothran (Ed.). The internet: opposing viewpoints, pp. 79-87. San Diego, CA: Greehaven. 2002.

5. Beard, I. A. and Harper, C. Students perceptions of online versus on campus instruction. Education, 122, pp. 658-663. 2002.

6. Benhunan-Fich, R. and Arbaugh, J.B. Separating the effect of knowledge construction and group collaboration in learning outcomes of web-based courses. Information \& Management, 43, pp. 778793. 2006.

7. Brown, D. and Ellison, C. What is active learning? In S. Hatfield (Ed), The seven principles in action: Improving undergraduate education, pp. 39-54. Boston: Anker. 1995.

8. Carr-Chellman, A. A. Desperate technologists: Critical issues in e-learning and implications for higher education. Journal of Thought, 4(1), pp. 95-119. 2006.

9. Carrell, 1. J. and Menzel, K. E. Variations in learning, motivation, and perceived immediacy between live and distance education. Communication Education, 50(3), pp. 230-241. 2001.

10. Conrad, R. and Donaldson, J. A. Engaging the online learner: Activities and resources for creative instruction. San Francisco: Jossey-Bass. 2004.
11. Gunawardena, C. N. and Zittle, F. J. Social presence as a predictor of satisfaction within a computer-mediated conferencing environment. American Journal of Distance Education, 11(3), pp. 8-26. 1997.

12. Hiltz, S. R. and Turoff, M. What makes learning networks effective? Communications of the ACM, 45(4), pp. 5659. 2002.

13. Jackson, M. J, Helms, M. M. Student Perceptions of hybrid Courses: Measuring and Interpreting Quality. Journal of Education for Business, September/October, 2008.

14. Killian, D. The education evangelist at Safari Books Online discusses the ins and outs of e-learning. Computerworld, September 29, 2008.

15. Klesius, J. P. Homan, S. and Thompson T. Distance education compared to traditional education: the students' view. International Journal of Instructional' Media, 24, pp. 207-222. 1997.

16. Kuh, G. D. What we're learning about student engagement from NSSE. Change, 35, pp. 24-31. 2003.

17. Maeroff, G. I. A classroom of one: How online learning is changing our schools and colleges. New York: Palgrave MacMillan. 2003.

18. McFarland, D. and Hamilton, D. Factors affecting students performance and satisfaction: Online vs. traditional course delivery. Journal of Computer Information Systems, 46(2), pp. 25-33. 2005.

19. Norton, P. and Hathaway, D. Exploring Two Teacher Education Online Learning Designs: A Classroom of One or Many? Journal of Research on Technology in Education, 40(4), pp. 475-495. 2008.

20. Palloff, R. and Pratt, K. Lessons from cyberspace classroom. San Francisco: Jossey-Bass. 2001.

21. Pethokoukis, J. M. E-learn and earn: As dot coms mostly fade, online universities are proving that there's gold in them that screens. U.S. News and World Report, 132(22), p. 36. June 24, 2002. 
22. Pittinsky, M. S. The wired tower: Perspectives on the impact of the Internet on higher education. Upper Saddle River, NJ: Pearson Education. 2003.

23. Plotrowski, C. and Vodanovich, S. J. Are the reported barriers to Internet-based instruction warranted? A synthesis of recent research. Education, 121, pp. 48-53. 2000.

24. Ponzurick, T. France, K. and Logar, C. Delivering graduate marketing education: an analysis of face-to-face versus distance education. Journal of Marketing Education, 22, pp. 180-187. 2000.

25. Reynolds, J. Indicators of educational effectiveness. In S. Hatfield (Ed). The seven principles in action: Improving undergraduate education, pp. 107-114. Boston: Anker. 1995.

26. Robinson, C. and Hullinger, H. New Benchmarks in Higher Education: Student Engagement in Online Learning. Journal of Education for Business. November/December, 2008.
27. Rovai, A. P. Sense of community, perceived cognitive learning, and persistence in asynchronous learning networks. Internet and Higher Education, 5, pp. 319-332. 2002.

28. Russell, T. No significant difference phenomenon. 2006.Available from: Http://www.nosignificantdifference.org [accessed 01/23/2010].

29. Shen, J. Hiltz, S. R. and Bieber, M. Collaborative Online Examinations: Impacts on Interaction, Learning, and Student Satisfaction. IEEE Transactions on Systems, Man, And Cybernetics- part A: Systems And Humans, 36(6), pp. 1045-1053. 2006.

30. Simonson, M. Entering the mainstream: Distance education and higher education. Quarterly Review of Distance Education, 6(1), VII. 2005.

31. Wagner, E. D. In search of a functional definition of interaction. American Journal of Distance Education, 8(2), pp. 6-26. 1994. 